\title{
Autonomy in Language Teaching and Learning Process
}

\author{
Dilek ÇAKICI \\ Ondokuz Mayıs University, Faculty of Education
}

\begin{abstract}
:
The concept of learner autonomy in the field of foreign language learning was clearly articulated in the 1979 report prepared by Holec for the Council of Europe. The learner autonomy aims at providing language learners with the ability to take on more responsibility for their own learning. In addition, students may make decisions by themselves about what and how they should learn. On the other hand, traditionalists assert that providing autonomy to learners will cause teachers to lose their control over the class. In this review, the concept of learner autonomy in language learning has been explained from different aspects. Afterwards, the necessary clues regarding how to support the development of learner autonomy in language learning process are given and the characteristics of autonomous learners are presented. In addition, the ways recommended to promote the learner autonomy are discussed and the roles of both teachers and learners in developing of autonomy are mentioned.
\end{abstract}

Keywords: Language learning, Language teaching, Learner autonomy.

İnönü University

Journal of the Faculty of Education

Vol 16, No 1, 2015

pp. 31-42

DOI: $10.17679 /$ iuefd. 16168538

Submitted : 12.03.2015

Revised : 09.04.2015

Accepted : 12.05.2015

\section{Suggested Citation}

Çakıcı, D. (2015). Autonomy in language teaching and learning process. Inönü Üniversitesi Eğitim Fakültesi Dergisi, 16(1), 31-42. DOI: 10.17679/iuefd. 16168538 


\section{INTRODUCTION}

Learner autonomy, especially in the field of foreign language learning was clearly articulated in the 1979 report prepared by Holec for the Council of Europe under the title of Autonomy in Foreign Language Learning. As for the philosophical background of learner autonomy, the starting point to encourage learners to become more autonomous is to have them accept the responsibility for their own learning. According to Holec (1981), learners should be given the responsibility to make decisions concerning all aspects of their own special learning styles, capacities and needs. Fener and Newby (2000), Benson (1997) argue that constructivist theories of learning constitute the major theoretical background for the psychological aspect of learner autonomy. In view of pedagogical background, Fener and Newby (2000) point to the fact that each individual has a unique way of constructing his or her own world. Each generates rules and mental models so that they make sense of experiences. Learning is a search for meaning. Therefore, learning must start with issues around which students actively try to construct meaning. The key to succeed in learning depends on allowing each individual to construct his or her meaning, not make them memorize and repeat another person's meaning. In formal learning environments, learners can be enabled to construct their own personal learning spaces in accordance with their personal and educational needs. It seems that if learners are given a share of responsibility in the decision-making processes regarding dimensions such as pace, sequence, mode of instruction, and content of study, learning could be "more focused and more purposeful, and thus more effective both immediately and in the longer term" (Little, 1991, p.8). According to Benson, "the key idea that autonomy in language learning has borrowed from constructivism is the idea that effective learning is active learning" (2001, p. 40).

Learner autonomy grows out of the individual learner's acceptance of responsibility for his/her own learning. This means that learner autonomy is a matter of explicit or conscious intention: one cannot accept responsibility for her/his own learning unless $s /$ he has some idea of what, why, and how s/he tries to learn.

Autonomy is an elusive notion that is somewhat difficult to get hold of. In general, it denotes a significant measure of independence from external control. This is, however, balanced by our mutual dependence on each other in society. Thus, it is a question of social interdependence. According to Little (1991), autonomy is essentially a "capacity-for detachment, critical reflection, decision-making, an independent action" (p.4). The term autonomy has been used in five ways as follows (Benson and Voller, 1997, p. 2):

1. situations in which learners study entirely on their own,

2. an inborn capacity which is suppressed by institutional education,

3. a set of skills which can be learned and applied in self-directed learning,

4. the right of learners to determine the direction of their own learning,

5. the exercise of learners' responsibility for their own learning.

All the definitions of learner autonomy have a common point: they refer to the concept that learners are involved in their own learning process. Through this involvement they clearly connect their beliefs, ideas, and thoughts with the world outside the classroom. In the case of language learning, it is to be able to use the target language apart from the classroom or their learning environment. In this way, learning becomes more than a way of rote memorization and it continues even after schooling finishes. To improve language learning, Little (1991) believes that students should have control over the goals and content of the learning they are involved in. Students with a high meta-cognitive awareness, which is a must in fostering learner autonomy, have the ability to address their weaker points easily and can also take precautions accordingly in a more successful way.

\section{Development of Autonomy through Language Teaching}

Littlewood (1997) makes a detailed explanation on how autonomy develops in a language learner through the process of language learning. He starts his explanation by distinguishing three kinds of autonomy to be developed relevant to language teaching as follows: Language teachers aim to develop students' ability to operate independently with the language and use the language to communicate in real, unpredictable situations. Language teachers aim to help their students to develop their ability to take responsibility for their own learning and to apply active, personally meaningful strategies to their work both inside and outside the classroom. Helping their students to increase their ability to communicate and learn 
independently, language teachers also try to reach the goal of helping their students to develop greater generalized autonomy as individuals. Then, in language teaching teachers need to help students develop motivation, confidence, knowledge and skills that they require in order to communicate more independently, to learn more independently and to be more independent as individuals. Littlewood uses Figure 1 to illustrate the development of autonomy through language teaching.

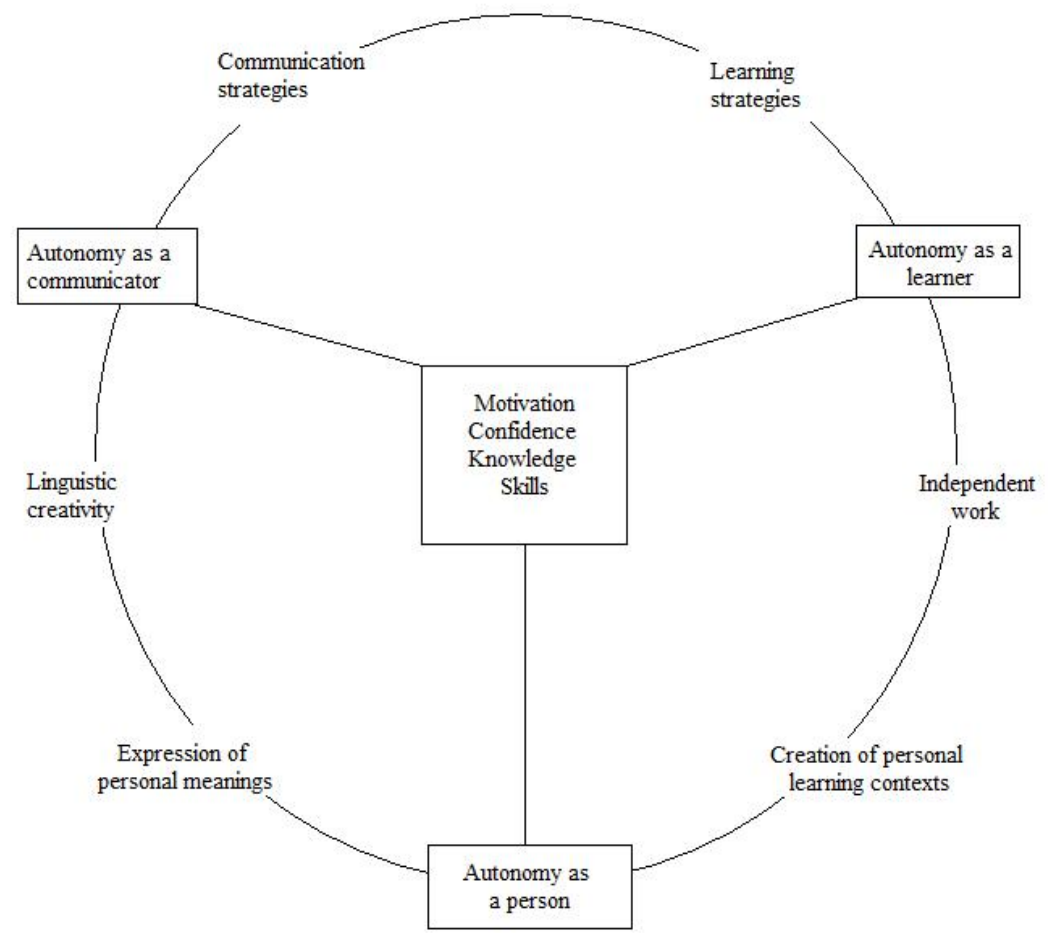

Figure 1. Developing autonomy through teaching (Littlewood, 1997, p.83)

In Figure 1, the center box contains the four components which contribute to a learner's willingness and ability to act independently. The three boxes show the overlapping kinds of autonomy (Autonomy as a communicator, Autonomy as a learner, Autonomy as a person) which students can develop. The six additional labels around the circle: Communication strategies, Learning strategies, Linguistics creativity, Independent work, Expression of personal meanings, Creation of personal learning contexts show some of the concrete ways to express three kinds of autonomy in learning. Each way is placed next to the kind of autonomy to which it relates most closely. That is, expressing linguistic creativity by the creative use of language and/or employing communication strategies in order to convey meanings demonstrate and develop language learners' independence as communicators. Applying personal learning strategies and/or engaging in independent work, language learners demonstrate and develop their ability as independent learners. Creating their personal learning contexts and/or expressing their personal meanings, language learners demonstrate and develop their autonomy.

\section{Autonomy and Language Learning}

It is a commonly held view that language learning is greatly enhanced when a student has control over the goals and the content of a course of study (Little, 1991; Dam, 1995). Helping students to develop autonomous learning capacities can be approached in a number of ways. These approaches are often given under an umbrella term of learner training and may consist of awareness raising, scaffolding, strategy training, increased social interaction, and the encouragement of reflection.

Whatever the teacher does in the classroom is inevitably shaped by her or his unique system of personal constructs: "you are yourself, in some sense, what you teach" (Salmon, 1995, p. 28). Teacher autonomy is grounded in the uniqueness of each individual teacher, but if dialogue is a reciprocal process, teachers' understanding as teachers must develop in interaction with the development of their learners' understanding. Teachers no less than learners have a "virtual other" to feed. 
Three pedagogical principles may be suggested to express the characterization of an autonomous learner in language classroom: 1. learner empowerment, 2. reflectivity, and 3. appropriate target language use (Little, 1991).

\section{The Principle of Learner Empowerment}

It entails that teachers bring their learners to accept responsibility for their own learning. A truly dialogic process entails joint exploration: teacher's understanding should grow along with that of their learners. If it does not, that is a sure sign that teachers are standing outside the process, going through the motions rather than engaging with their teaching in the way that they demand their learners should engage with their learning.

\section{The Principle of Reflectivity}

It is already implied by the principle of learner empowerment. In the autonomous language classroom, reflection begins as a collaborative activity in which teacher and learners seek to make explicit their joint understanding of the process they are engaged in. Reflection must be pursued as a routine that retains this meaning because the scope of the learners' responsibility is always expanding outwards, which means that the reach of their reflection is always being extended. Reflection on the learning process is another key component of learner autonomy. By reflecting on the learning process, learners become aware of how and why they choose the methods and strategies they use in different projects, and for solving different tasks. Being aware of the learning process helps makes them autonomous (Turloiu and Stefansdottir, 2011).

According to Clark (1997), reflection is unlikely to progress far without the support of writing because:

1. It is by writing things down that we provide ourselves with something to reflect on in the first place.

2. It is easier for teachers to step back from their own utterances and thoughts when they have been written down,

3. The reflective process itself is greatly facilitated if teachers use written notes to help them work out what they think.

When reflection is explicitly focussed on the learning process, it is likely to take account of motivation and affect; but it should always try to focus on the specific quality of the experience that gave rise to positive or negative feelings. For that is how learners gradually become aware that a growing capacity for metacognitive control nurtures intrinsic motivation.

\section{The Principle of Appropriate Target Language Use}

It requires that from the earlier stages teachers must engage their learners in forms of exploratory dialogue that require them to use the target language to express their own meanings. They must help students to construct and maintain multiple scaffolding in writing and in speech; and they must include in appropriate target language use the activities required by the principle of reflectivity. The three principles of learner empowerment, reflectivity, and target language use do not refer to three discrete aspects of the language teaching-learning process. Rather, they offer three closely related perspectives on one holistic phenomenon, the web of pedagogical dialogue that is partly in interaction between the participants in the process and partly in each participant's head. Their consistent and sustained pursuit produces a learning community in which teaching is learning, learning involves teaching, and language learning is inseparable from language use.

In an autonomous classroom the starting point is not the textbook but the learners. It should be considered that each member of the class has interests, and emotional as well as educational and communicative needs. It should be considered that learning is not a simple matter of the unidirectional transmission of knowledge, skills, and expertise. On the contrary, it is a bidirectional process, for anything can only be learned in terms of what we already know.

Learning is also a messy and indeterminate process, impossible to control except in rather superficial ways. Learner autonomy comes into play as learners begin to accept responsibility for their own learning. But they can do this only within the limits imposed by what they already know and what they have already become. What is called the textbook approach to language teaching involves learning "from the outside in"; the textbook author's meanings are first learnt and then gradually adapted to the learners' own 
purposes. The autonomous approach, by contrast, insists that language is learnt partly "from the inside out", as learners attempt to express their own meanings for their own learning purposes (Dam, 1995). In the autonomous approach, learning is anchored in the achieved identity of the individual learner and the interactive processes by which learners collaboratively construct their shared learning space.

\section{Characteristics of an Autonomous Learner}

Many researchers in the relevant literature have suggested different characteristics related to autonomous learners. Candy (1991) states the characteristics of autonomous learners are as follows: methodical and disciplined; logical and analytical; reflective and self-aware; curious, open and highly motivated; flexible, interdependent and interpersonally competent; persistent and responsible; venturesome and creative; and self-sufficient, information seekers, knowledgeable and skilful about learning process and critical thinkers.

According to Dickinson (1993), although quite a lot of learners actually do not know what is going on in their classes, autonomous learners are able to identify what has been taught. They are able to formulate their own learning objectives in collaboration with teacher, or as something that is in addition to what the teacher is doing. In addition, autonomous learners can select and implement appropriate learning strategies consciously, and they can monitor their own use of learning strategies. Lastly, autonomous learners should monitor their own learning and self-assessment. Cotterall (1995, p. 199) agrees with Dickinson on self-assessment as she says "it is essential that learners be able to evaluate the quality of their learning. An appreciation of their abilities, the progress they are making and of what they can do with the skills they have acquired is essential if learners are to learn efficiently." According to Holec, 1981; Little, 1991, basically, autonomous learners are those who take charge of their own learning. They are aware of their personal and educational needs and can determine the objectives and goals for their own learning. Also, they can establish a link between what is to be learned, how to learn, and the resources available. They develop a capacity that enables them to define the content and progression of their learning, select methods and techniques to be used, monitor the procedures of acquisition and evaluate what has been acquired." In addition, Cotterall (1995, p. 200) states that "autonomous learners are likely to be individuals who have overcome the obstacles which educational background, cultural norms and prior experience may have put in their way." Following the above definition, learners, first and foremost, become willing and ready for the change learner autonomy requires. However, in non-western cultures, because most of the learners are already traditionally and culturally conditioned, they cannot be expected to become willingly and ready for change (Chan, 2001). Additionally, learners are provided with time to experience and become aware of their strengths, the individual's sense of identity, and independence (Dam, 1995; Finc, 2000). In other words, as a prerequisite, learners have the capacity that enables them to detach, monitor, think critically, evaluate and reflect their own learning process independently and cooperatively (Little, 1991; Benson, 2001). The capacity learner autonomy necessitates may be innate or may be learned afterwards. The capacity whether it is innate or learned afterwards may grow with practice or it may be lost if it is not used (Holec, 1981; Little, 1991).

Another prerequisite for the promotion of learner autonomy on the part of learner is awareness. Language awareness can be defined as explicit theoretical knowledge about the nature of the language, and consciousness perception and sensitivity in language learning, language teaching and language use. Learners need to be consciously aware of how language systems work and what they need for an effective learning process. Similar to capacity, awareness may also develop naturally and gradually and learners thus may start taking initiatives by exercising and nourishing their capacity. Through awareness learners may set up learning goals, plan and practise learning activities, select and use appropriate learning strategies, monitor their progress, and actively engage in the learning process (Holec, 1981).

\section{Ways to Foster Learner Autonomy in English Teaching and Learning}

\section{Teaching Learning Strategies}

According to Oxford, learning strategies are "... specific actions taken by the learner to make learning more easier, faster, more enjoyable, more self-directed, more effective and more transferable to new situations" (1989, p. 8). In other words, learning strategies refer to characteristics we want to stimulate in students to enable them to become more proficient language learners (Oxford, 1990, p.11). Strategies are the tools for active, self-directed involvement needed for developing L2 communicative ability (O'Malley and Chamot, 1990). Research has repeatedly shown that the conscious, tailored use of such strategies is 
related to language achievement and proficiency. In addition, Rubin and Wenden view learning strategies as "behaviours learners engage in to learn and regulate the learning of a second language" (1987, p. 6). In that sense, fostering learner autonomy involves cultivation of learning strategies. In order to learn autonomously, teachers should give students adequate training to prepare them for more independent learning. O' Malley and Chamot (1990) believe that learning strategies have learning facilitation as a goal and are intentional on the part of learner. The goal of strategy use is to affect the learner's motivational or affective state, or the way in which the learner selects, acquires, organizes or integrates new knowledge (Weinstein and Mayer, 1986). A series of learning strategies are the key to learner autonomy, aiming at maximizing learner autonomy. Language learners need training in learning strategies in order to increase their potential and contribute to their autonomy. Indeed, the teacher should be a model in the use of strategy using. The teacher's job is not only to teach language, but to teach learning. For the students, strategies have to be learned. The best way to do this is with "hands-on" experience. Students need to become independent, self-regulated learners. Self-assessment contributes to learner autonomy (Freeman and Anderson, 2011). Metacognitive strategies go beyond the cognitive mechanism and give learners to coordinate their learning. This helps them to plan language learning in an efficient way. As Oxford (1990) states that metacognition refers to learners' automatic awareness of their own knowledge and their ability to understand, control and manipulate their own cognitive processes. Meta-cognitive is a term to express executive function, strategies which require planning for learning, thinking about the learning process as it is taking place, monitoring of one's production, evaluating learning process.

Social strategies are very important in learning a language because language is used in communication and communication occurs between people. Three sets of strategies are included in this group: Asking Questions, Cooperating with others, and Empathizing with others. Among the three, cooperation with others eliminates competition and in its place brings group spirit. Studies show that cooperative learning results in higher self-esteem, increased confidence, and rapid achievement. Learners do not naturally apply cooperative strategies because of strong emphasis put on competition by educational institutions. Sometimes competition brings a strong wish to perform better than others, but it often results in anxiety and fear of failure. It is important to help learners change their attitudes from confrontation and competition to cooperation. Empathy is very important in communication. Empathy means to put oneself in someone else's situation to understand that person's point of view. Learners can use social strategies to develop cultural understanding and become aware of thoughts and feelings of others (Oxford, 1990).

In addition, socio-affective strategies help learners to interact with other persons or employ affective control to assist learning. O'Malley, Chamot, Stewner-Manzanares, Russo, and Küpper (1985, pp. 582-584) suggested socio-affective strategies such as Cooperation and Question for Clarification. These strategies entail working with one or more peers to obtain feedback, or model a language activity and asking a teacher for repetition, explanation or examples, creating situations to practice the language with others, using activity. Language learners need training in learning strategies in order to increase their potential and contribute to their autonomy. Indeed, the teacher should be a model in the use of strategy using. Affective refers to emotions, attitudes, motivations and values (Oxford, 1990, p.140). The affective factors like emotion, attitude, motivation, and values influence learning in an important way. Three sets of strategies are included in this group: Lowering Your Anxiety, Encouraging Yourself, and Taking Your Emotional Temperature. Good language learners control their attitudes and emotions about learning and understand that negative feelings retard learning. Teachers can help generate positive feeling in class by giving students more responsibility, increasing the amount of natural communication, and teaching affective strategies. Techniques like self-reinforcement and positive self-talk which help learners gain better control over their emotions, attitudes, and motivations related to language learning (Oxford, 1993).

\section{Using Cooperative Learning}

Since cooperative language learning is an approach designed to foster cooperation rather than competition, to develop critical thinking skills and to develop communicative competence through socially structured interaction activities, these can be regarded as the overall objectives of CLL. Learners are directors of their own learning. They are taught plan, monitor and evaluate their own learning which is viewed as a compilation of lifelong learning skills. Therefore, cooperative learning is a powerful approach for learner autonomy. Its aim is to establish a community of learners in which students are able to generate questions and discuss ideas freely with the teacher and each other. According to Johnson (1991), cooperative learning incorporates five elements: positive interdependence; face-to-face interaction, 
individual accountability and personal responsibility; interpersonal and small group skills and group processing. Positive interdependence occurs when group members feel that what helps all and what hurts one member hurts all. It is created by the structure of CL tasks and by building a spirit of mutual support in the group. Students are encouraged not to think competitively and individualistically, but rather cooperatively and in terms of the group. Teachers not only teach language; they teach cooperation as well. Since social skills involve the use of language, cooperative learning teaches language for both academic and social purposes (Freeman and Anderson, 2011). Group formation is an important factor in creating positive interdependence.

\section{Self-Reports}

According to Wenden (1998), a good way of collecting information on how students go about a learning task and helping them become aware of their own strategies is to assign a task and have them report what they are thinking while they are performing it. This self-report is called introspective, as learners are asked to introspect on their learning. In this case, "the introspective self-report is a verbalization of one's stream of consciousness" (Wenden, 1998, p. 81). Introspective reports are assumed to provide information on the strategies learners are using at the time of the report.

Another type of self-report is what has been named as retrospective self-report, since learners are asked to think back or retrospect on their learning. Retrospective self-reports are quite open-ended, in that there is no limit put on what students say in response to a question or statement that points to a topic in a general way. There are two kinds of retrospective self-reports: semi-structured interviews and structured questionnaires. A semi-structured interview may focus on a specific skill with a view to extracting information about learners' feelings towards particular skills (reading, listening, etc.), problems encountered, techniques resorted to tackle these problems, and learners' views on optimal strategies or ways of acquiring specific skills or dealing with learning tasks. A structured questionnaire seeks the same information but in a different way: by means of explicit questions and statements, and then asking learners to agree or disagree, write true or false, and so forth.

\section{Diaries and Evaluation Sheets}

Perhaps one of the principal goals of education is to alter learners' beliefs about themselves by showing them that their putative failures or shortcomings can be ascribed to a lack of effective strategies rather than to a lack of potential. After all, according to Vygotsky, learning is an internalised form of formerly social activity, and "a learner can realize his potential interactively through the guidance of supportive other persons such as parents, teachers, peers" (Wenden, 1998, p. 107). Herein lays the role of diaries and evaluation sheets, which offer students the possibility to plan, monitor, and evaluate their learning, identify any problems they run into and suggesting solutions.

\section{Learner Autonomy through Portfolio Creation}

Portfolio creation leads to more autonomous learning. It includes planning yourself and achieving the plan, taking responsibility for your own role, setting goals for yourself, heading toward them and doing what you have to do, and making a decision about something on your own. Learners should have opportunities to discover what a portfolio is and the purposes of portfolio creation. They can do so by examining sample portfolios and sharing each other's work in progress. The instructor can also explain the purposes explicitly to them. Moreover, Shimo (2003, p. 175) suggests that providing "optional tasks which allow students to make choices" and "decision-making tasks which enable students to plan and organize their learning." will help learners feel the sense of autonomy. Also, the portfolio leads the learner to reflective and metacognitive process which is key factors in autonomy.

Thomsen (2010) revealed that the portfolio helped learners talk about their learning experiences, and assume an active role in their learning. Learners could share with their peers their learning experiences by reflecting in writing on their thoughts and ideas. Portfolios are convenient tools for teachers in the process of getting to know the learners closely as individuals and as learners of English. In addition, it is useful when choosing strategies for individual learners or groups of learners. The European Language Portfolio (ELP) supports the development of learner autonomy by self-assessment and goal setting. The learners are expected to record how they progress in the target language and any intercultural experiences they may 
have during the learning process (Little, 2005). ELP is a document kept by language learners, at school and outside school, to log and reflect on their learning and cultural experiences when learning a language. The ELP aims to motivate learners and help them keep a comprehensive record of their linguistic and cultural skills. It acknowledges their efforts to develop and diversify their language skills at all levels. One of its various objectives is to build up learners' motivation by improving their communicative skills in the target languages.

Göksu and Genç (2011) investigated the contribution of the ELP to autonomy in the reading skills of Turkish learners of English by looking at the learners' perceptions of the ELP as part of their learning process. The majority of the students felt positive towards the ELP and, under its influence, studied autonomously in reading. Most of the students realized that they read in English on their own, evaluated themselves and developed their reading skills themselves. Some students who had not previously enjoyed reading books or learning foreign languages had their views changed by the ELP which made them feel more positive about learning a foreign language and more courageous in reading. The development and practise of learner autonomy require the full involvement of the learner in planning, monitoring and evaluating learning. Such involvement entails the development of explicit skills of reflection and analysis. Learner autonomy is thus a matter of learning how to learn intentionally. The successful implementation of learner autonomy solves the problem of learner motivation: if learners are involved in their learning they exploit but also nourish their intrinsic motivation (Deci and Ryan, 1985).

\section{Teacher Roles}

For the implementation and development of learner autonomy, teachers play an important role because they are responsible for developing a learning environment conductive to promoting learner autonomy. However, it is pointed out that in order to promote learner autonomy in the teaching contexts, teachers need freedom so that they can apply their own autonomy in teaching.

Learner autonomy is based on the idea that teachers teach how to learn. Therefore, teachers, first, recondition learners while assisting them to develop a conscious awareness of their language learning strategies and their effectiveness, and their beliefs about the language learning process. Additionally, teachers train learners to gradually become more active, reflective and critical thinkers in using learning strategies for their own learning as well as encouraging them to initiate experimental practice inside and outside classroom. Moreover, teachers involve learners in the decision making process. Teachers encourage learners to set up reachable learning goals based on the feedback from evaluation and selfassessment (Dam, 1995). The teachers' role in the development of autonomy has also been investigated by Voller (1997) who found that teachers must have a clear view of the attitudes and beliefs underpinning their views of autonomous language learning. He states that whether the teacher views learner autonomy as a right or as a distant goal, the teacher role-plays the facilitator, counselor and resource. Voller (1997) also proposes the following three fundamental assumptions which lead to autonomy. The first is that language learning is an interpretive process therefore; an autonomous approach to learning requires a transfer of control to the learner. The second is to make sure that our teaching practices reflect these assumptions by ensuring that they are based on a process of negotiation with learners. And the third is to self-monitor our teaching so as to observe and reflect upon the teaching strategies we use and the nature of the interactions we set up and participate in.

Learner autonomy requires teachers to act as catalysts, discussants, consultants, observers, analysts, facilitators and counsellor to stimulate the learning process in various ways (Little, 1991). Furthermore, teachers are supportive, patient, tolerant, emphatic, open and non-judgmental. To support learner autonomy, teachers consider learners as their partners in achieving common goals. They motivate learners by encouraging commitment and self-confidence. As partners, teachers help learners overcome obstacles. They are always ready to enter a dialogue with learners (Wenden, 1998; Benson, 2001).

For the promotion of learner autonomy in foreign language classes, teachers help learners set objectives, plan works, select materials, evaluate themselves, and acquire the skills and knowledge needed. Teachers also change students' concepts about the traditional role of the teacher and the learner in the classroom. As a part of this awareness-raising process, teachers explain explicitly objectives and reasons for particular activities. Teachers train learners to help them identify learning styles, appropriate learning strategies and more importantly, the utility of learner autonomy and necessity for autonomous learning. Besides, teachers 
let us learners make mistakes, and to choose learning materials so that learners may have more influence on their own learning process. Teachers respect learners' ways of handling tasks (Benson, 2001). Therefore, teacher's support is highly demanding to develop students' awareness, to identify learners' needs in terms of strategy use, and to adopt different ones they will become autonomous learners and remove many barriers that exist in education. The students should be exposed to more strategies. A teacher should offer them a list of learning strategies, experiment with new ones, and help them choose the ones that are best suited to their learning styles.

As Seeman and Tavares (2000) assert that it is easier to implement learner autonomy in classes that are used to pair and group work. Group work is one of the foundations of the learner autonomous environment. Group work is a key factor in the learner autonomous classroom and something that many teachers struggle with. Not everyone has the ability to take part in group work successfully. It depends on a combination of social and cognitive skills, which the individual members of any group will only possess in widely varying degrees. This is why knowing how to handle the gradual development of effective group dynamics is one of the fundamental skills required of a good teacher (Little, 2000). Dişlen (2011) investigated how freshmen students from different departments of a Turkish university perceive the concept of responsibility within an EFL context. The students are in favour of group work. Moreover, they place a high value on guidance and the presence of a teacher during the learning process. They show a dependency on the teacher while learning English. Therefore, they assign different roles to teachers such as giving lectures, motivating students, facilitating the process and providing guidance. Though they seem to be dependent learners, they are aware that students should be responsible for their own learning; thus, they specified their roles as studying, exerting an effort to learn.

\section{CONCLUSION \& SUGGESTIONS}

In present paper, it is aimed to describe the concept of learner autonomy in language learning has been explained from different aspects. Certain clues about how to support the development of learner autonomy in language learning process are presented and the characteristics of autonomous learners are stated. In addition, the ways recommended to promote the learner autonomy are discussed and the impact of both teachers and learners on developing of autonomy are mentioned.

Apart from being an important issue in daily life and education, autonomy is especially important in language learning. This is due to the novel changes, i.e. learner-centred curriculum, the negotiated syllabus, learner training, the Project-based syllabus and learner-based teaching which occurred in 1980s and 1990s put learners as individual into the core of language learning process. Learner-centred approaches have reshaped the roles of the teacher and learner, mainly their power and authorities, and then language learners have taken greater responsibility of their learning. As a result, autonomy and autonomous learner have become prominent themes in language education.

Autonomy is a situation in which the learner makes his/her own decisions and has the opportunity for independent action during the process of learning. One of the basic ways of helping learners gain autonomy is to teach learning strategies. So as to provide the learners with a learning environment in which they can learn in an autonomous way, the learners should receive strategy training. In other words, the teachers should train students about how to develop and use effective strategies for their learning. In addition, the teachers should present training activities which aim to increase students' knowledge of useful ways to learn and develop the strategies they need (Hedge, 2000). Second, the principle of cooperative learning is one of the factors to be considered in creating autonomous learners. The reason is that it aims to establish a classroom environment in which learners can generate questions and discuss them in a free way with the teacher and each other. Third, a significant element of making an autonomous English language classroom is the use of portfolios. Portfolios contain a record of concrete examples of student work done over time. They can accurately demonstrate a learner's progress in the target language, give learners the opportunity to reflect on their own progress and work collaboratively with peers even after the actual assessment has been given. Also, they help learners take responsibility for their own progress toward both class-oriented and personal learning goals. With the use of portfolios, learners can document the planning, learning, monitoring, and evaluation process.

The roles of teachers in developing learner autonomy are much more directive of the purpose. They have strategic place in creating an autonomous language classroom for learners. From understanding their 
learners' needs and interests to designing activities accordingly, from negotiating with learners about all the tasks to helping them to make self-evaluation teachers have lots of roles. Teachers who are aware of the need for cultivating students' capacity for autonomous learning should also create a supportive environment in which they address the need for new and different assessment procedures in the learning process. Teachers of EFL should concentrate on developing learners' positive attitudes towards becoming autonomous learners. Indeed, all the things in the classroom should be supportive and encouraging so that learners can gain the confidence to take charge of their own learning. These roles provide autonomy to learners; consequently create an autonomous classroom.

Learner autonomy in teaching English as a foreign language holds a central place in the field. First, learners are involved in their learning; they are quite active; so their learning is more efficient. It stems from the fact that the process of learning is more personal and more focused. Next, effective communication through a language is possible by using it practically, as is generally known. Finally, as the speed level and some other variables of learning a foreign language may change from learner to learner, the matter of individual and individualisation finds its solution in the concept of learner autonomy.

As Benson (2001) points out, the teacher cannot teach students to become autonomous. But, the teacher may create such atmosphere and conditions in which they will be encouraged to develop the autonomy that they already have. Parallel to this, Lee (1998) argues that human beings are born with autonomy.

Moreover, autonomy is usually accepted as essentially implying particular skills and behaviours and particular methods of organising teaching and learning process. Autonomy is considered as a multidimensional concept which takes different context of learning. Benson (2001, p. 82) criticizes these approaches because they make the term more confusing and complex than it is, and suggests that autonomy is not "a method of learning, but an attribute of learner's approach to the learning process."

Autonomy is an elusive notion that is somewhat difficult to get hold of. In general, it denotes a significant measure of independence from external control. This is, however, balanced by our mutual dependence on each other in society; thus it is a question of social interdependence. According to the influential definition by Little (1991, p. 4) autonomy is essentially a "capacity - for detachment, critical reflection, decisionmaking, and independent action." For autonomy to increase, the student needs to develop a particular kind of psychological relation to the process and content of learning.

An ideal foreign language class that promotes learner autonomy should be designed as a rich and natural learning environment where learners test and investigate new things with the help of the same interactive mechanism they used in first language acquisition. Learners are encouraged to participate in making decisions related to their own learning. Teachers give up some of the control mechanisms and become facilitators. Thus, evaluation is an integral part of the course and learning process becomes visible in this type of class. However, learners are given limited control over the classroom activities they participate in. Many different activities with different contents are suggested in classrooms in which learner autonomy is a desired goal. Learner autonomy highly favours pair and group work rather individual work in the classroom because pair and group work develop learners' capacity to use the target language. In addition, learners learn how to talk to negotiate meaning, convey the message, and listen for a reason so that they can establish links between classroom and the world outside the school, and improve their social abilities as well as their proficiency levels (Dam, 1995; Nunan, 1999; Benson, 2001).

Despite the ever-expanding literature, learner autonomy remains a minority pursuit; perhaps because of all forms of autonomisation threaten the power structures of educational culture. The Council of Europe's European Language Portfolio, however, is a tool that may bring autonomisation to much larger numbers of learners. The ELP was first launched as a concept in 1997 and has since been realised in almost 40 different models, all of which conform to Principles and Guidelines lay down by the Council of Europe.

What it is suggested, therefore, is that prospective teachers should be provided with the skills to foster autonomy. In other words, language teachers are more likely to succeed in promoting leaner autonomy if their own education has encouraged them to be autonomous. In that sense, to make the students more autonomous language learner, teachers should become less of an instructor and more of a facilitator. In other words, students are discouraged from relying on the teacher as the main source of knowledge. Students' capacity to learn for themselves and to make decisions about what they learn should be 
encouraged. In addition, Students should be trained to employ learning strategies and provided chance to discover their own learning styles. In order to provide permanent and effective learning, teachers should make use of language learning strategies. Teachers should gain great deal of knowledge and skill about language learning strategies. Firstly, teachers should discover their own strategies, consider new ones, learn how to model and teach them. The great burdens should be placed on teachers to provide learners many opportunities to practice. Teachers should decide suitable teaching techniques and methods, and plan how they will integrate strategy-based instruction into curriculum. Besides, foreign language departments should determine and adopt an inclusive point of view as to language learning strategies and help prospective foreign language teachers to have an adequate awareness about necessity and use of strategy based instruction. More highly motivated learners use a significantly greater range of appropriate strategies than do less motivated learners. Motivation is related to language learning purpose, which is another key to strategy use. For instance, individuals who want to learn a new language mainly a new language merely to fulfill a graduation requirement, the learners should be trained to assess themselves objectively. The teacher should involve learners in a non-stop quest for good learning activities, which are shared, discussed, analyzed and evaluated with the whole class. Tok (2011) examined preparatory level students in a Turkish university reported that they were engaged in a variety of autonomous activities while learning English in a university-based program. He also explored the relationship Autonomous Language Learning: Turkish tertiary students' behaviours between their self-reported levels of autonomous learning activity and both their English proficiency level and their self-assessed level of motivation. The results of the study indicate that the students' English proficiency and motivation level are significantly and positively related to their autonomous activities. It is possible to say, based on the results, that students are more engaged in autonomous activities when their English proficiency and motivation levels are high.

In addition, teachers should help learners to set their own learning targets and choose their own learning activities, subjecting them to discussion, analysis and evaluation. Teachers should require learners to identify individual goals but pursue them through collaborative work in small groups. Teachers should require her learners to keep a written record of their learning - plans of lessons and projects, lists of useful vocabulary, whatever texts they themselves produce. Lastly, teachers should engage learners in regular evaluation of their progress as individual learners and as a class (Little, 1995).

\section{REFERENCES}

Benson, P. and Voller, P. (1997). Autonomy and independence in language learning. New York: Longman.

Benson, P. (2001). Teaching and researching autonomy in language learning. London: Longman.

Candy, P. C. (1991). Self-direction for lifelong learning. California: Jossey-Bass.

Chan, V. (2001). Readiness for learner autonomy: What do our learners tell us? Teaching in Higher Education, 6(4). 505-519.

Clark, A. (1997). Being there. Putting brain, body, and world together again. Cambridge, MA: MIT Pres.

Cotterall, S. (1995). Readiness for autonomy: Investigating learner beliefs. System, 23(2), 195-206.

Dam, L. (1995). Learner autonomy: From theory to classroom practice. Dublin: Authentik.

Deci, E. L. and Ryan, R. M. (1985). Intrinsic motivation and self-determination in human behavior. New York: Pienum.

Dickinson, L. (1993). Talking shop: aspects of autonomous learning: An interview with Leslie Dickinson. ELT Journal, 47(4), 330-336.

Dişlen, G. (2011). Fostering autonomy in language learning. D. Gardner (Eds.), Exploration of how students perceive autonomous learning in an EFL context. pp.126-136). Zirve University: Gaziantep.

Fener, A. B. and Newby, D. (2000). Approaches to materials design in European textbooks: Implementing principles of authenticity, learner autonomy, cultural awareness. European Centre for Modern Languages of the Council of Europe Publishing.

Finch, A. E. (2000). A formative evaluation of a task-based EFL program for Korean university students. Unpublished Doctoral Dissertation, Manchester University, Manchester, UK.

Freeman, D. and Anderson, M. (2011). Teaching and principles in language teaching. Oxford University Press. Oxford.

Göksu, A. and Genç, B. (2011). Fostering autonomy in language learning. In D. Gardner (Eds.), The contribution of the European language portfolio to autonomy in reading skills. (pp. 99-106). Zirve University: Gaziantep.

Hedge, T. (2000). Teaching and learning in the language classroom. Oxford University Press.

Holec, H. (1981). Autonomy in foreign language learning. Oxford: Pergamon Press. 
Johnson, D. W. (1991). Human relations and your career (3rd.ed.). Englewood Cliffs, NJ: Prentice-Hall.

Lee, I. (1998). Supporting greater autonomy in language learning. ELT Journal, 52(4), 3-10.

Little, D. (1991). Learner autonomy: Definitions, issues and problems. Dublin: Authentik.

Little, D. (2000). Why focus on learning rather than teaching? In D. Little, L. Dam, and J. Timmer (Eds.), Focus on Learning Rather than Teaching: Why and how? Papers from the International association of teachers of English as a foreign language 48 (IATEFL) Conference (Krakow, Poland, May 14-16, 1998). (pp. 3-17). Dublin Ireland: Centre for Language and Communication Studies. Trinity College.

Little, D. (2005). The Common European Framework and the European Language Portfolio: involving learners and their judgements in the assessment process. Sage journals online, 2-17.

Littlewood, W. (1997). Self-access work and curriculum ideologies. In P. Benson and P. Voller (Eds.), Autonomy and independence in language learning. (pp. 181-191). London: Longman.

Nunan, D. (1999). Second language teaching and learning. Massachusetts: Heinle\&Heinle.

O'Malley, J. M., Chamot, A. U., Stewner-Manzanares, G., Russo, P., and Küpper, L. (1985). Learning Strategy applications with students of English as a second language. TESOL Quarterly, 19(3), 557-584.

O'Malley, J. M., \& Chamot, A. V. (1990). Learning strategies in second language acquisition. London: Macmillan.

Oxford, R. (1989). The use of language learning strategies: A synthesis of studies with implications for strategy training. System, 12(2), 235-247.

Oxford, R. (1990). Language Learning Strategies: What every teacher should know. Boston, MA: Heinle \& Heinle.

Oxford, R. (1993). Research on second language strategies. Annual Review of Applied Linguistics, 13, 175187.

Rubin, J. and Wenden, A. (1987). Learner strategies in language learning. Englewoods Hill, NJ: Prentice Hall.

Salmon, P. (1995). Psychology in the classroom. Reconstructing teachers and learners. London and New York: Cassell.

Seeman, T. and Tavares, C. (2000). Getting the learners involved in their own learning - how to get started. In D. Little, L. Dam, \& J. Timmer (Eds.), Focus on learning rather than teaching: Why and how? Papers from the International Association of Teachers of English as a Foreign Language (IATEFL) Conference (Krakow, Poland, May 14-16, 1998) (pp. 59-70). Dublin: Centre for Language and Communication Studies.

Shimo, E. (2003). Learners' perceptions of portfolio assessment and autonomous learning. In A. Barfield and M. Nix (Eds.), Teacher and learner autonomy in Japan, Autonomy you ask! (pp. 175-186). Tokyo: Japan Association for Language Teaching Learner Development Special Interest Group.

Thomsen, H. (2010). Writing and talking to learn - a portfolio study. In teaching English at lower secondary level and EFL learning and second language acquisition: Reading handouts (pp. 191-202). Reykjavík: University of Iceland.

Tok, H. (2011). Fostering autonomy in language learning. In D. Gardner (Eds.), Autonomous language learning: Turkish tertiary students' behaviours. (pp.126-136). Zirve University: Gaziantep.

Turloiu, A. and Stefansdottir, I. S. (2011). Learner autonomy: Theoretical and practical information for language teachers. Reykjavik: University of Iceland.

Voller, P. 1997. Does the teacher have a role in autonomous learning? In P. Benson and P. Voller (Eds.), Autonomy and independence in language learning. (pp. 98-113). London: Longman.

Wenden, A. (1998). Learner strategies for learner autonomy. Great Britain: Prentice Hall.

Weinstein, C.E. and Mayer, R.E. (1986). The teaching of learning strategies. In M. Wittrock (Eds.), Handbook of research on teaching (pp. 3 15-327). New York, NY: Macmillan,

Correspondence

Assist. Prof.Dr. Dilek ÇAKICI Ondokuz Mayıs University, Faculty of Education,

ELT Department. dcakici@omu.edu.tr 